\title{
Responsive Polydiacetylene Vesicles for Biosensing Microorganisms
}

\author{
Estelle Lebègue $^{2, *}$, Carole Farre ${ }^{1}$, Catherine Jose ${ }^{1}$, Joelle Saulnier ${ }^{1}$ (D), Florence Lagarde ${ }^{1}$ (iD), \\ Yves Chevalier ${ }^{3}$ (D), Carole Chaix ${ }^{1}$ (iD) and Nicole Jaffrezic-Renault ${ }^{1, * \text { (ID }}$ \\ 1 Institute of Analytical Sciences, University of Lyon, 69100 Villeurbanne, France; \\ carole.farre@isa-lyon.fr (C.F.); catherine.jose@isa-lyon.fr (C.J.); joelle.saulnier@univ-lyon1.fr (J.S.); \\ florence.lagarde@isa-lyon.fr (F.L.); carole.chaix-bauvais@univ-lyon1.fr (C.C.) \\ 2 Institute of Chemical Sciences, University of Rennes 1, 35000 Rennes, France \\ 3 University of Lyon, LAGEP, 69622 Villeurbanne, France; yves.chevalier@univ-lyon1.fr \\ * Correspondence: estelle.lebegue@univ-rennes1.fr (E.L.); nicole.jaffrezic@univ-lyon1.fr (N.J.-R.); \\ Tel.: +33-437-423-558 (N.J.-R.)
}

Received: 12 January 2018; Accepted: 14 February 2018; Published: 15 February 2018

\begin{abstract}
Polydiacetylene (PDA) inserted in films or in vesicles has received increasing attention due to its property to undergo a blue-to-red colorimetric transition along with a change from non-fluorescent to fluorescent upon application of various stimuli. In this review paper, the principle for the detection of various microorganisms (bacteria, directly detected or detected through the emitted toxins or through their DNA, and viruses) and of antibacterial and antiviral peptides based on these responsive PDA vesicles are detailed. The analytical performances obtained, when vesicles are in suspension or immobilized, are given and compared to those of the responsive vesicles mainly based on the vesicle encapsulation method. Many future challenges are then discussed.
\end{abstract}

Keywords: vesicles; polydiacetylene; biosensing; bacteria; toxins; virus; peptides

\section{Introduction}

The demand for new sensing technologies that can serve as alerts for bacterial contamination has significantly increased in recent years because of incidents of food poisoning, bioterrorism alerts, and anthrax scares. Numerous technologies for bacterial detection have been developed [1]. Nevertheless, many methods employed for pathogen sensing provide results after relatively long time spans (several hours to days in the case of culture-based methods). Other currently employed technologies often involve complex detection mechanisms that require specialized instrumentation, trained personnel, and the need for complex sample preparation, which overall do not make possible uses in settings outside laboratory environments.

Polydiacetylene (PDA) has attracted significant scientific and technological interest in recent years because of its unique chromatic properties. Specifically, PDA has been shown to self-assemble into organized vesicles and films, forming an ene-yne conjugated framework that absorbs light in the visible region of the electromagnetic spectrum and consequently appears intensely blue [2]. Furthermore, it has been shown that external perturbations, primarily affecting the reorganization of the pendent polymer side-chains as a result of enhanced surface pressure, give rise to stress-induced structural transformations of the PDA backbone, resulting in dramatic blue-to-red transitions. PDA also exhibits interesting fluorescence properties: no fluorescence is emitted by the initially polymerized blue-phase PDA, whereas the red-phase PDA strongly fluoresces.

Synthetic vesicles or liposomes based on phospholipids mixed with polyacetylene have been extensively used for mimicking cell membranes [3]. For this purpose, the molecular system produced should retain, as much as possible, the physico-chemical properties of the actual cell membrane (such 
as lipid and protein organization and fluidity). The elaboration of biosensors for hemolytic bacteria is based on the detection of their emitted toxin that has the specific property of forming pores in the cell membrane. Screening of molecules with antibiotic properties is also based on the specific properties of these molecules to form pores in the cell membrane. This review paper reports the main recent works that present PDA vesicle-based assays, involving this phenomenon, for the detection of bacteria, bacterial toxins and antibiotic peptides. The direct detection of bacteria based on the specific interaction with antibody- and aptamer-functionalized PDA vesicles is also reported, and both principles of detection are compared in terms of selectivity and sensitivity. The direct detection of viruses based on the specific interaction with receptor-functionalized PDA vesicles is also reported. The analytical performance of PDA vesicle-based assays is moreover compared to that of other types of responsive vesicles, involving mainly the vesicle encapsulation method.

Reviews of synthetic vesicles are mainly focused on vesicle encapsulation methods that enhance the sensitivity of sandwich immunoassays [4,5]. This aspect will not be included herein.

\section{Physicochemical Characteristics of PDA Vesicles}

\subsection{Structure and Synthesis of PDA Vesicles}

Synthetic or natural surfactants that can self-assemble as bilayers are the elementary molecules of vesicles or liposomes. The most common surfactants forming liposomes are phospholipids, the surface-active compound present in cell membranes; liposomes can then mimic biological membranes [3]. The structure of vesicles depends on the dispersion process [6]. The most common structures are multilamellar large vesicles (MLV), small unilamellar vesicles (SUV) of sub-micron diameter made of a single closed bilayer membrane, and giant unilamellar vesicles (GUV) of a few tens of micron in diameter (Figure 1).

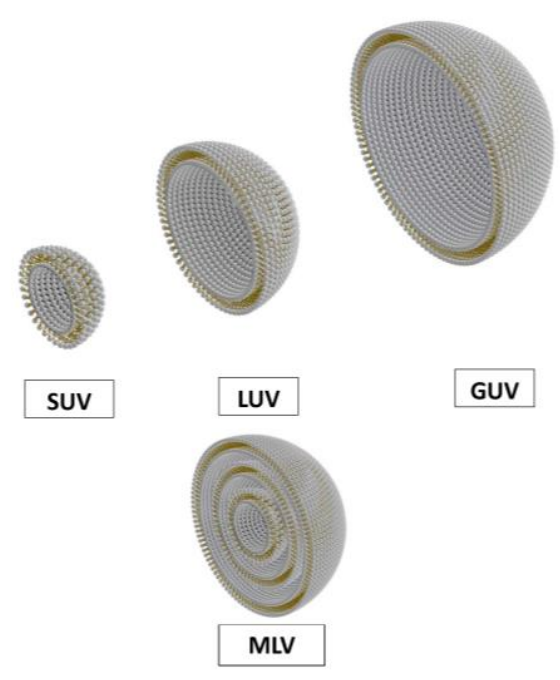

Figure 1. Different structures of vesicles: SUV (small unilamellar vesicles), LUV (large unilamellar vesicles), GUV (giant unilamellar vesicles), and MLV (multilamellar large vesicles). Vesicles are presented as hemivesicle to show the inside.

The PDA vesicles are all unilamellar vesicles composed of one spherical mixed bilayer encapsulating probes or not. The general procedure for their preparation is summarized as follows: A mixture of phospholipids and diacetylenic acid is completely dissolved in chloroform [7], which is then evaporated. The dry lipid film is hydrated by the addition of an aqueous solution. The vesicle solutions are extruded through polycarbonate membranes or sonicated. Polymerization of PDA is then performed under UV light $(254 \mathrm{~nm})$. 
The study of the influence of the UV doses on the stability of vesicles has shown that a higher degree of PDA polymerization improves their overall stability [8]. Moreover, the passive leakage of entrapped probes (i.e., fluorescent probes) is minimized when the degree of PDA polymerization is increased [8]. The composition of the lipid mixture can influence the biomimetic behavior of the obtained film, as demonstrated in Ref. [9].

Size-controlled fabrication of supramolecular vesicles using a microfluidic chip has been described [10]. The mean and standard deviation of the diameters of PDA vesicles produced by using the bulk method are respectively 88 and $31 \mathrm{~nm}$ and those of vesicles prepared with the microfluidic method are, respectively, 39 and $12 \mathrm{~nm}$.

\subsection{The Colorimetric Response of the PDA Vesicles and Formats of the PDA Vesicle-Based Assays}

One of the more fascinating aspects of polydiacetylene chemistry is the color and chromism of the materials. The energy of electronic excitations, and therefore the color of the material, can be dependent upon many factors such as the original packing state of the monomers and the exposure of the polymeric material to environmental perturbations such as heat (thermochromism), mechanical stress (mechanochromism) or solvent (solvatochromism). The blue-to-red transition is associated with a conformational change of the PDA backbone from planar to non-planar and then more conjugated, the side chains being more ordered in the red phase. The color transitions of the polymerized vesicles are monitored by visible absorption spectroscopy: 620-640 nm (PDA blue form) and 490-540 nm (PDA red form) [2]. PDA red form also presents a fluorescence emission in the range 520-700 nm, when excited at $488 \mathrm{~nm}$. As an example, colorimetric and fluorescent detection of melamine through PDA vesicles were compared. The intra/inter hydrogen bonding between melamine and the cyanuric acid receptor at the PDA vesicle surface induces perturbation of the PDA backbone and results in rapid and sensitive colorimetric/fluorescence change of the PDA vesicle. A detection limit of $1.0 \mathrm{ppm}$ is obtained for colorimetric PDA liposome and $0.5 \mathrm{ppm}$ for fluorescent PDA vesicle array [11].

The format of the colorimetric/fluorescence assay can be as that of a multiwell plate when vesicles are free in solution (see, for instance, Ref. [12]). To miniaturize the assay, patterned arrays are formed through the immobilization of vesicles on surfaces. Different surface modifications have been proposed for vesicle immobilization: aldehyde [13,14], amine [14,15] and $\alpha$-cyclodextrin [16] functionalizations. An interlinker, ethylenediamine, which acts as a cross-linker between individual PDA vesicles, allows stabilization of PDA vesicles on a solid surface and the fluorescence signal is ten times higher than for the array without the interlinker [17].

\subsection{The Physico-Chemical Characterization of the PDA Vesicles}

Of the many physicochemical characterization methods used thus far, light scattering and microscopy methods provide the clearest information regarding the morphology of vesicles.

Dynamic light scattering (DLS) measurements allow the diffusion coefficient of the vesicles in the liquid suspension to be determined. This diffusion coefficient is converted into a mean diameter using the Stokes-Einstein relationship under the hypothesis that vesicles are spherical in shape. This assumption can be unsuitable when vesicles are flexible and their shape strongly fluctuates; this is the cases of large unilamellar vesicles. DLS does not allow the user to infer the shape or discriminate between unilamellar and multilamellar vesicles, nor does it allow detection of pores or holes through the lipid bilayer, nor discrimination between closed bilayer (vesicles) and fragments of bilayers (bicelles). DLS provides quite satisfactory data in the case of vesicles smaller than $1 \mu \mathrm{m}$. Nanoparticle tracking analysis (NTA), where the trajectories of individual scattering objects are observed under a microscope and their displacement is related to each object's size, is considered the gold standard technique for PDA vesicle characterization. Both techniques are influenced by shape in the same manner.

Transmission electron microscopy (TEM) provides high resolution pictures of the vesicles, allowing the discrimination of unilamellar and multilamellar vesicles, and possibly the thicknesses of 
the lipid bilayers and the water layers in between them (in the case of multilamellar vesicles). Classical TEM requires the samples to be dried before observation, so drying is not expected to change the organization, and the images should reveal the structure present in the aqueous suspension. It is often useful to enhance the contrast using heavy metal staining agents such as uranyl acetate. Again, it is hoped that staining will not disturb the structure. Either cryo-TEM or TEM of a replica prepared by the freeze-fracture technique allows more reliable observations of the structure prevailing in the liquid suspension. An example of such images of large unilamellar and multilamellar giant vesicles, made of bilayers of synthetic double chain zwitterionic surfactants [18], is given in Figure 2.
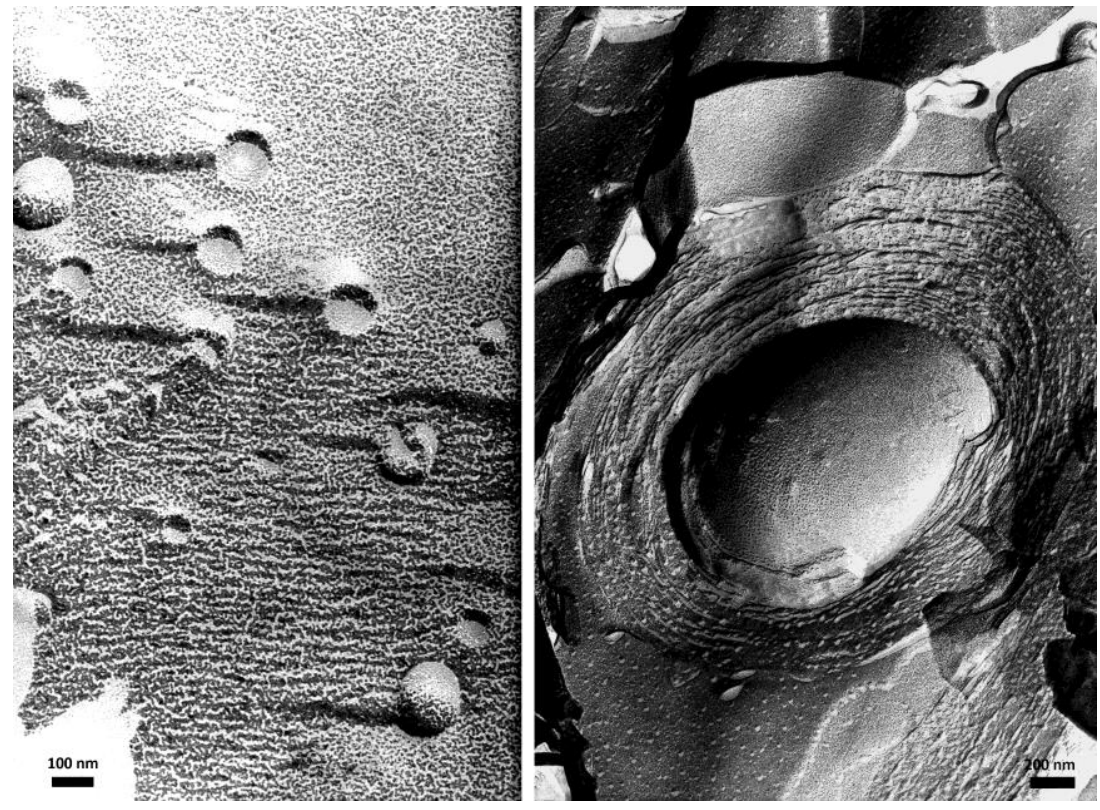

Figure 2. TEM images of large unilamellar vesicles (LUV) (left) and multilamellar giant vesicles (MGV) (right), made of bilayers of synthetic double chain zwitterionic surfactants, taken after preparation by freeze-fracture and replication of the fracture section. LUV appear as small circles being either full or having an empty water pool inside depending on whether the fracture propagated across the vesicles or along their external surface. MGV appear as onion-like stacks of lipid bilayers. Such concentric bilayers fill the whole vesicle; the empty hole in the middle corresponds to part of the vesicle center that has been detached when fracturing the frozen sample.

The colloidal stability of PDA vesicles requires strong enough repulsions between them to prevent coagulation. Quite strong electrostatic repulsions come from the presence of the anionic carboxylic groups as heads of PDA chains. Electrostatic effects can be assessed by electrophoretic measurements of the zeta potential. Since most charged species are salts of weak acids, it is wise to measure the zeta potential as a function of $\mathrm{pH}$ and determine the isoelectric point. Efficient electrostatic stabilization requires the $\mathrm{pH}$ to be shifted by at least one or two units from the isoelectric point.

The most interesting formulations of lipid components on the organization of lipid membranes could also be investigated by compression in a Langmuir trough. The pressure-area isotherms of mixed monolayers including the same lipid components are registered, giving information on the overall lipid compaction. The elasticity of a PDA mixed Langmuir film was studied in Ref. [19].

Atomic force microscopy [20] and Total Internal Reflection Fluorescence (TIRF) allows the shape and of the viscosity of the individual biomimetic vesicles to be evaluated. TIRF single vesicle measurements were performed to determine the vesicle rupture lag time in the presence of antiviral peptides [21]. It was demonstrated that C5A peptide presents a potent vesicle rupture activity, this activity being independent of vesicle diameter. AH peptide is highly membrane-active while it preserves vesicle size-selectivity. This point influences the range of enveloped viruses that is targeted. 


\section{Transducing Principles and Preparation of Responsive Biomimetic Vesicles}

Two main transducing principles are implemented in responsive biomimetic vesicles:

(1) Biomimetic PDA vesicles, PDA being used as a transducer for biological sensing, have been used as useful platforms for analysis and rapid screening of biomolecular recognition events [22]. Conjugated PDA is a remarkable polymeric system which exhibits unique organization and chromatic properties. This polymer has a strong blue color, due to electron delocalization within the conjugated double bonds, giving rise to absorption at around $650 \mathrm{~nm}$ in the visible region of the electromagnetic spectrum. Importantly, PDA can undergo both rapid blue-red color transitions (upper lines in Figure 3) and concomitant fluorescence transformations (lower lines in Figure 3), induced by external stimuli such as surface binding, insertion or pore formation, which disturb electron distribution along the polymer chains.

(2) Other types of responsive vesicles are based on the vesicle encapsulation method: fluorescent dye or redox species being encapsulated in the vesicle. These assays were mainly for the detection of species presenting pore-forming functions such as bacterial toxins or antibacterial substances (Figure 4).
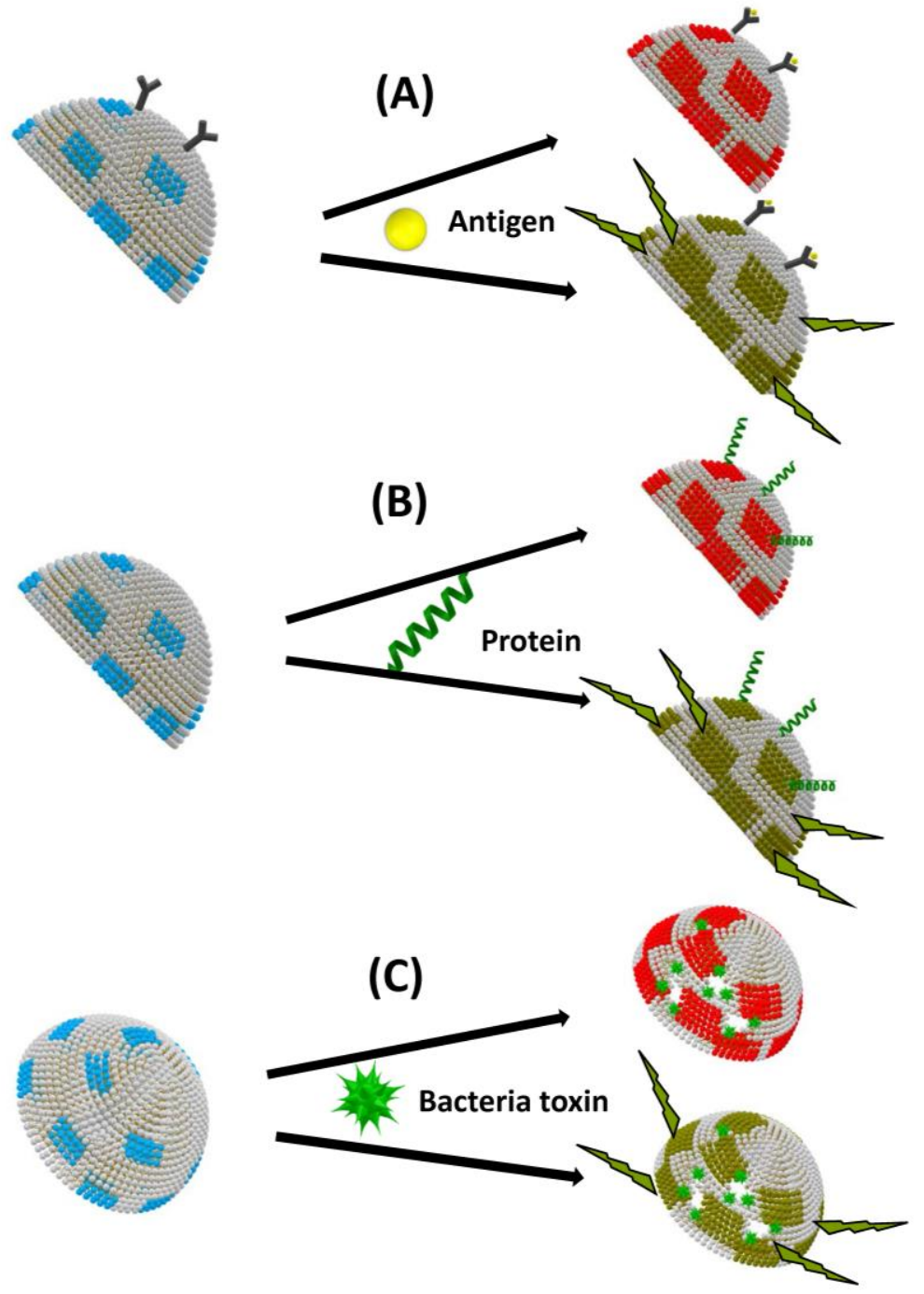

Figure 3. Colorimetric (upper line) and fluorescence (lower line) biosensing based on biomimetic vesicles comprising polydiacetylene (PDA) (blue and red parts) induced by external stimuli: (A) surface binding; (B) insertion; and (C) pore formation. Vesicles are presented as hemivesicles. 


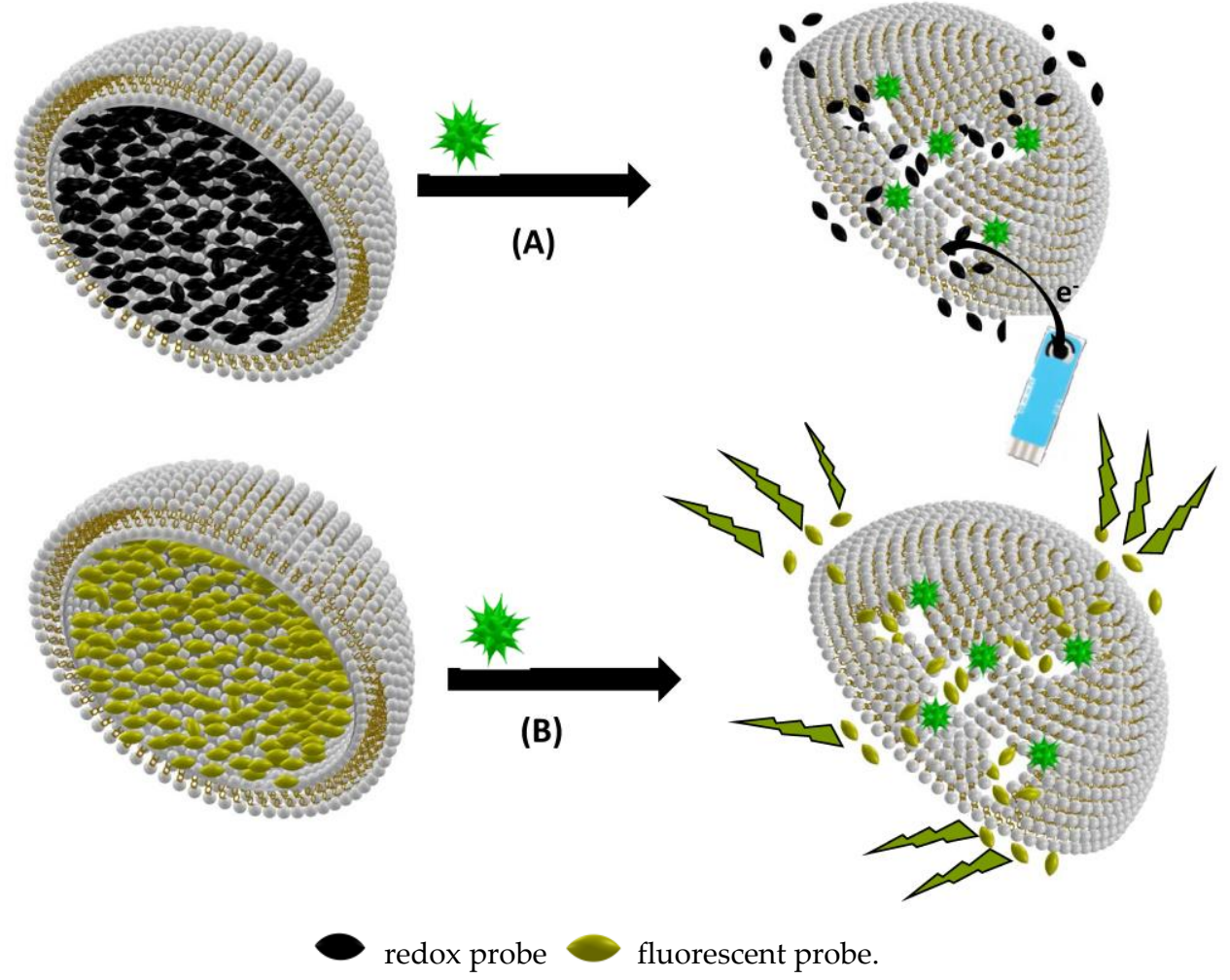

Figure 4. (A) Amperometric biosensing based on biomimetic vesicle encapsulation of redox probes; and (B) fluorimetric biosensing based on biomimetic vesicle encapsulation of fluorescent probes. Vesicles are presented as hemivesicles to show the inside.

An example of fluorescent vesicle-based biosensor for organophosphorous pesticides (OP) detection was developed by encapsulating the enzyme acetylcholine esterase and the pyranine fluorescent indicator in an egg phosphatidylcholine liposome. The enzyme substrate passes through porine channels and induces a decrease of pyranine fluorescence signal by decreasing the local $\mathrm{pH}$. When the enzyme is incubated with OP, its activity decreases, inducing an increase of the fluorescence signal in the presence of the same concentration of substrate [23]. Another fluorescent liposome based system contains specific pyrenyl amphiphiles: upon the interaction with the target enzyme, thymidine phosphorylase, the variation of excimer/monomer ratio allows its presence to be specifically detected [24].

\section{PDA Vesicle-Based Assays for Bacteria Detection}

\subsection{Direct Detection of Bacteria}

The published papers dealing with the direct detection of bacteria that use mixed PDA vesicles are based on optical detection: colorimetric detection due to blue-red transition of PDA under mechanical stress or fluorescence detection in the presence of a fluorophore grafted on a diacetylenic acid chain (Table 1). The interaction with the bacteria membrane can be ensured by the following specific molecules 
Table 1. PDA vesicles for detection of bacteria.

\begin{tabular}{|c|c|c|c|c|c|}
\hline Composition of the Bilayer & $\begin{array}{l}\text { Diameter of } \\
\text { Vesicles }(\mu \mathrm{m})\end{array}$ & $\begin{array}{c}\text { Type of } \\
\text { Transduction }\end{array}$ & $\begin{array}{l}\text { Type of } \\
\text { Bacteria }\end{array}$ & $\begin{array}{l}\text { Bacteria LOD } \\
\text { (CFU/mL) }\end{array}$ & Reference \\
\hline TCDA $/ 2 \%$ DGG & & Colorimetry & $\begin{array}{c}\text { E. coli } \\
\text { (ATCC25922) }\end{array}$ & Not given & [25] \\
\hline HCDA/DL3 & & Colorimetry & E. coli & $10^{8}$ & [26] \\
\hline $\begin{array}{l}\text { PCDA-ABA/PCDA-biotin-streptavidin-anti } \\
\text { E. coli antibody } /(20-30 \%) \text { DMPC }\end{array}$ & & Fluorescence & E. coli & $1.2 \times 10^{7}$ & [27] \\
\hline $\begin{array}{c}\text { PCDA/glucose-tagged lipid or } \\
\text { glucose-PCDA/rhodamine tagged } \\
\text { DMPC }\end{array}$ & 15-60 (GUVs) & $\begin{array}{l}\text { Colorimetry } \\
\text { Fluorescence } \\
\text { (FRET) }\end{array}$ & E. coli & $3.3 \times 10^{5}$ & [28] \\
\hline TRCDA/DMPC & & Colorimetry & E. coli & $\begin{array}{l}10^{8} \text { (drinking } \\
\text { water) }\end{array}$ & [29] \\
\hline $\begin{array}{l}\text { PCDA vesicles functionalized with LPS } \\
\text { binding aptamer }\end{array}$ & & Colorimetry & $\begin{array}{c}\text { E. coli } \\
\text { (O157:H7) }\end{array}$ & $10^{4}$ & [30] \\
\hline $\begin{array}{c}\text { PCDA/SPH/cholesterol/Lysine } \\
\text { Lysine concentration } 6.7 \mu \mathrm{g} / \mathrm{mL} \text {, pH } 6.5\end{array}$ & 0.2 & Colorimetry & S. choleraesuis & $10^{8}$ & [31] \\
\hline $\begin{array}{c}\text { PCDA/SPH/cholesterol/Lysine } \\
\text { Lysine concentration } 6.7 \mu \mathrm{g} / \mathrm{mL}, \mathrm{pH} 6.0\end{array}$ & 0.2 & & S. choleraesuis & $\begin{array}{l}10^{0}-10^{1} \text { in } \\
\text { chicken meat }\end{array}$ & [32] \\
\hline
\end{tabular}

DGG: dioctadecyl glycerylether- $\beta$-glucoside; DL3: 3,6,9,12-tetraoxa-10-cholest-2-acetamido-2-desoxy- $\beta$-D-glucopyranoside; DMPC: 1,2-dimysristoyl-sn-glycero-3-phosphatidylcholine; GUVs: giant unilamellar vesicles; HCDA: 2,4-heneicosadiynoic acid; LOD: limit of detection; LPS: lipopolysaccharide; MLVs: multilamellar vesicles; PCDA: 10,12-pentacosadyinoic acid; PCDA-ABA: 10,12-pentacosadyinoic acid grafted with abscisic acid; PCDA-biotin: 10,12-pentacosadyinoic acid grafted with biotin; SPH: sphingomyelin; TCDA: tricosa-2,4-diynoic acid; TRCDA: 10,12-tricosadiynoic acid.

(1) either inserted in the bilayer membrane: long chain glucoside [25,26,28] and sphingomyelin [31,32]

(2) or grafted on the diacetylenic acid chain: antibody [28] and aptamer [30].

The colorimetric detection of ligand/receptor interactions through physical incorporation of receptors within lipid/PDA vesicles offers important advantages over chemical attachment of recognition units to the PDA itself. First, the chemical derivatization of PDA can be technically demanding and the organic synthesis procedures limit the scope of this approach. Furthermore, attaching additional chemical units onto the diacetylene monomers often disrupts the organization and the self-assembly of the monomers and hence compromises polymerization. Consequently, the abundance of recognition modules in derivatized PDA vesicles is low. Such limitations are generally not encountered when the recognition element is incorporated in the lipid/PDA bilayer. This point is demonstrated when comparing the obtained detection limit using PCDA (10,12-pentacosadyinoic acid) functionalized with a LPS (lipopolysaccharide) aptamer $\left(10^{4} \mathrm{CFU} / \mathrm{mL}\right.$ of E. coli) [30] and the obtained detection limit with SPH (sphingomyelin) incorporated in a polyacetylene vesicle $(1-10 \mathrm{CFU} / \mathrm{mL}$ of S. choleraesuis) [32]. The latter PDA vesicle-based assay was also tested for other types of bacteria in a high concentration of bacteria: $10^{8} \mathrm{CFU} / \mathrm{mL}$. In Figure 5, it appears that P. aeruginosa was also detected [31]. The selectivity of detection is closely dependent on the recognition molecule as well as the solution conditions ( $\mathrm{pH}$ value) [31,32].

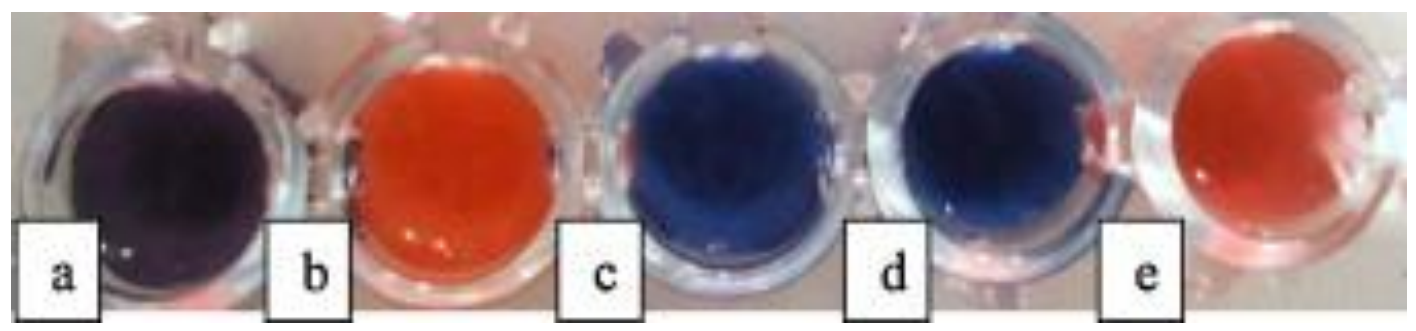

Figure 5. PCDA/SPH/Cholesterol/Lysine vesicles added to TSB $(0.1 \%)$ and aqueous saline at $\mathrm{pH} 6.0$ with: (a) E. coli; (b) P. aeruginosa; (c) S. aureus; (d) L. plantarum; and (e) S. Choleraesuis $\left(10^{8} \mathrm{CFU} / \mathrm{mL}\right)$. Reprinted with permission from [31]. Copyright 2017 Elsevier. 
Very rapid tests for the detection of bacteria in real samples were then designed using these mixed PDA vesicles for the detection of Salmonella choleraesuis in chicken meat [32].

Real time monitoring of the photocatalytic sterilization process in the presence of $\mathrm{TiO}_{2}$ colloid was obtained by recording the colorimetric response (blue-red transition) of mixed polydiacetylene vesicles in the presence of E. coli (Figure 6) [33].

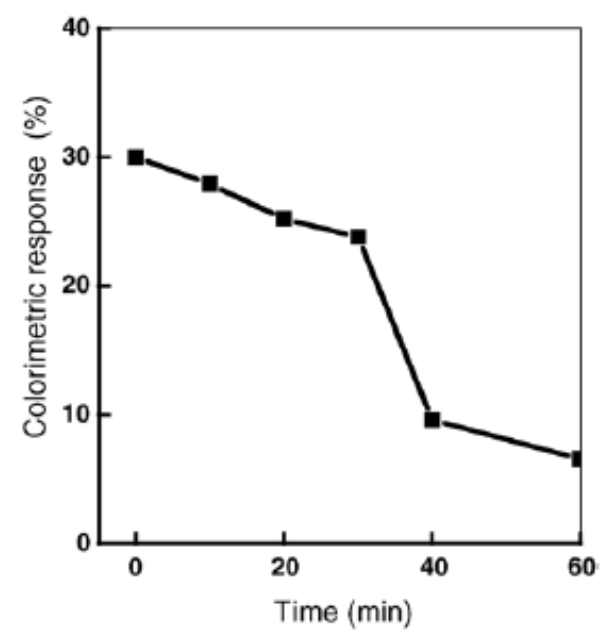

Figure 6. Colorimetric transition of mixed polyacetylene vesicles as a function of light irradiation time in the presence of $\mathrm{TiO}_{2}$ in E. coli $\mathrm{K} 12$ suspension. Reprinted with permission from [33]. Copyright 2005 Elsevier.

Bacterial RNA was detected by fluorescence measurements through conjugation with on-chip immobilized PDA vesicles, previously grafted with complementary DNA probes. Different types of crude cell lysate (E. coli, L. monocytogenes, and S. enteritidis) were incubated together with the specifically grafted vesicles. When target bacteria were matched with DNA probes, increased fluorescence intensities were observed. Although slight fluorescence, corresponding to non-specific signal, is detected, the level of fluorescence is much lower than that of matched probes. The detection limit was determined as $10^{4}-10^{5} \mathrm{CFU} / \mathrm{mL}[16]$.

\subsection{Indirect Detection of Hemolytic Bacteria through Toxin Detection}

Pathogenic bacteria produce a large variety of toxins and virulence factors. Hemolytic bacteria are pathogenic bacteria that produce pore-forming toxins, ultimately resulting in cell death by necrosis or apoptosis [34]. PDA liposomes have been synthesized to detect this type of toxins through electrochemical or optical methods (colorimetry or fluorimetry) (Table 2). To mimic the cell membrane, the mixed bilayer is composed of a mixture of phosphocholine (1,2-dipalmitoyl-snglycero-3-phosphocholine (DPPC), 1,2-bis(10,12-tricosadiynoyl)sn-glycero-3-phosphocholine (PCDIYNE), and 1,2-dimysristoyl-sn-glycero-3-phosphosphocholine (DMPC)), mixed with diacetylene monomers (glycine-terminated diacetylene monomer (GLY-PDA), 10,12-tricosadiynoic acid (TCDA), N-(10,12-pentacosadiunoyl)-glycine (Gly-PCDA), and 1,2-bis(10,12-tricosadiynoyl)sn-glycero-3phosphocholine (PC-DIYNE)) and cholesterol as a bait molecule, since the first step for pore formation is believed to be toxin binding to cholesterol. For electrochemical detection, redox compounds such as ferrocene, hexacyanoferrate or 2,6-dichlorophenolindophenol, are entrapped in the vesicles [35-38] or inserted in the bilayer membrane [36,37]. Using ferrocene-PDA based vesicles, when the toxin is trapped by the receptor (ganglioside GM1), the toxin-receptor complex blocks the charge transfer route of the ferrocene probes to the electrode surface [36]. 
Table 2. PDA vesicles for detection of hemolytic bacteria and toxins.

\begin{tabular}{|c|c|c|c|c|c|c|c|}
\hline Composition of the Bilayer & $\begin{array}{l}\text { Nature of the } \\
\text { Encapsulated } \\
\text { Probe }\end{array}$ & $\begin{array}{c}\text { Type of } \\
\text { Transduction }\end{array}$ & Type of Hemolytic Bacteria & Type of Toxin & $\begin{array}{c}\text { Toxin } \\
\text { LOD nM }\end{array}$ & $\begin{array}{l}\text { Bacteria LOD } \\
\text { (CFU/mL) }\end{array}$ & Reference \\
\hline \multicolumn{8}{|c|}{ Electrochemical detection } \\
\hline $\begin{array}{l}\text { GLY-PDA/Fc-PDA/receptor } \\
\text { ganglioside GM1 }\end{array}$ & & Amperometry & E. coli & $\begin{array}{c}\text { E. coli } \\
\text { Heat-labile } \\
\text { enterotoxin }\end{array}$ & 36 & & [36] \\
\hline $\begin{array}{l}\text { Phosphatidylcholine/cholesterol/ } \\
\text { diacetyl } \\
\text { phosphate/1-octadecanethiol }\end{array}$ & hexacyanoferrate & Amperometry & S. pyrogenes $\mathrm{A}$ and $\mathrm{C}$ & Streptolysin O & $\begin{array}{c}0.025 \\
5 \mathrm{HU}^{*}\end{array}$ & & [35] \\
\hline phosphatidylcholine & $\begin{array}{c}2,6- \\
\text { dichlorophenol/ } \\
\text { indophenol }\end{array}$ & Amperometry & L. monocytogenes NCTC 7973 & - & - & $5 \times 10^{6}$ & [37] \\
\hline $\begin{array}{l}\text { Phosphatidylcholine/2,6- } \\
\text { dichlorophenolindophenol }\end{array}$ & & Amperometry & L. monocytogenes NCTC 7973 & - & - & $5 \times 10^{5}$ & [37] \\
\hline DPPC/cholesterol/TCDA & hexacyanoferrate & Amperometry & $\begin{array}{l}\text { P. aeruginosa PAO1 } \\
\text { S. aureus USA300 }\end{array}$ & $\begin{array}{l}\text { Rhamnolipid } \\
\text { Delta toxin }\end{array}$ & $\begin{array}{l}11,000 \\
29,000\end{array}$ & & [38] \\
\hline \multicolumn{8}{|c|}{ Optical detection } \\
\hline Gly-PCDA/PC-DIYNE/cholesterol & & Colorimetry & S. pyrogenes $\mathrm{A}$ and $\mathrm{C}$ & Streptolysin O & $\begin{array}{c}0.10 \\
20 \mathrm{HU}^{*}\end{array}$ & & [39] \\
\hline DMPC $/ 10,12$-tricosadiynoic acid & & Colorimetric & Salmonella enterica & $\begin{array}{c}\text { Bacterial } \\
\text { supernatant }\end{array}$ & & $10^{9}$ bacteria & [40] \\
\hline Glycopolydiacetylene & & Colorimetry & $\begin{array}{l}\text { E. coli } \\
\text { O157:H7 }\end{array}$ & Shiga toxin & & $1.2 \times 10^{6}$ & [41] \\
\hline $\begin{array}{c}\text { DMPE /DMPE } \\
\text { /TCDA/cholesterol }\end{array}$ & carboxyfluorescein & Fluorescence & $\begin{array}{l}\text { P. aeruginosa PAO1 } \\
\text { S. aureus MSSA } 476\end{array}$ & & & $10^{4}$ & [42] \\
\hline PCDA/TDER & & Colorimetry & $\begin{array}{l}\text { S. aureus (ATCC 6538) } \\
\text { E. coli (ATCC 11229) }\end{array}$ & $\begin{array}{c}\text { Bacterial } \\
\text { supernatant }\end{array}$ & & $\begin{array}{l}10^{8} \text { (spiked } \\
\text { apple juice) }\end{array}$ & [43] \\
\hline DPPC / cholesterol/TCDA /DPPE & carboxyfluorescein & Fluorescence & P. aeruginosa & Rhamnolipid & 40,000 & $10^{6} \mathrm{CFU} / \mathrm{mL}$ & [44] \\
\hline Hyaluronic acid/caprolactone & $\begin{array}{c}\text { 7-amino-4- } \\
\text { methylcoumarin }\end{array}$ & Fluorescence & S. aureus & hyaluronidase & $47 \mathrm{U} / \mathrm{mL}$ & & [45] \\
\hline Amine terminated PDA & & $\begin{array}{l}\text { Colorimetry } \\
\text { Fluorescence }\end{array}$ & B. subtilis, $P$. aeruginosa & surfactin & 16,500 & $1.8 \times 10^{3}$ & [46] \\
\hline
\end{tabular}

DMPC: 1,2-dimysristoyl-sn-glycero-3-phosphosphocholine; DMPE: 1,2-dimysristoyl-sn-glycero-3-phosphoethanolamine; DPPC: 1,2-dipalmitoyl-sn-glycero-3-phosphocholine; DPPE: 1,2-dipalmitoyl-sn-glycero-3-phosphoethanolamine; Fc-PDA: $N$-(10,12-pentacosadiunoyl)acetylferrocene; Gly-PDA: glycine-terminated diacetylene monomer; GLY-PCDA: N-(10,12-pentacosadiunoyl)-glycine; GM1: ganglioside; LOD: limit of detection; PCDA: 10,12-pentacosadyinoic acid; PC-DIYNE: 1,2-bis(10,12-tricosadiynoyl)-sn-glycero-3-phosphocholine; TCDA: 10,12-tricosadiynoic acid; TDER: N-[(2-tetradecanamide)-ethyl]-ribonamide; ${ }^{*} \mathrm{HU}$ (hemolytic unit) is defined as the amount of protein that causes 50\% lysis of a $2 \%$ red blood cell suspension in PBS at pH 4.

The optical techniques are based on the direct colour change of PDA through pore formation [39-41,43,46] or on the detection of released dye previously encapsulated in the vesicles $[42,44,45]$.

Different types of toxins were detected such as steptolysin O from S. pyrogenes and rhamsolipid from P. aeruginosa.

For streptolysin $\mathrm{O}$, detected using amperometry via the redox probe (hexacyanoferrate) release, the obtained detection limit is $5 \mathrm{HU}$ (hemolytic unit) [35] while when detected by colorimetry through the blue-red transition, the obtained detection limit is $20 \mathrm{HU}$ [39], showing that the method of vesicle encapsulation leads to lower detection limits.

An intelligent hydrogel wound dressing has been made of a hydrated agarose film in which the fluorescent dye-containing vesicles were mixed with agarose and dispersed within the hydrogel matrix. The dressing indicated a clear fluorescent/color response within $4 \mathrm{~h}$, only observed when in contact with biofilms in the wound, produced by a pathogenic strain. (Figure 7) [47]. 


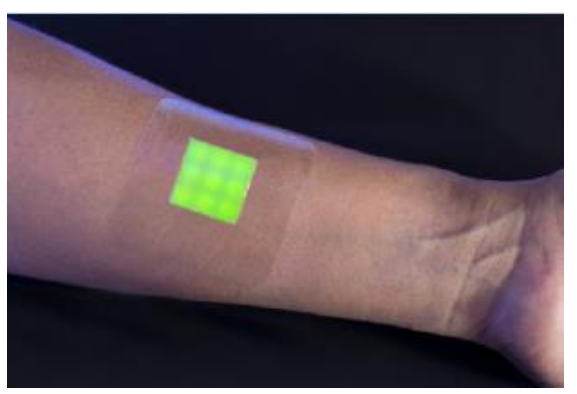

Figure 7. An intelligent hydrogel wound dressing based on fluorescent dye release from polydiacetylene vesicles. Reprinted with permission from [47]. Copyright 2016 American Chemical Society.

\subsection{Screening of Molecules with Antibiotic Properties}

Assays providing rapid, easy evaluation of the interactions between antimicrobial substances and PDA bilayer-based vesicles as the cell membrane model could significantly improve screening of substances with effective microbial properties, as well as contribute to the elucidation of their structural and functional properties.

Due to their optical properties, polydiacetylene based vesicles were generally used for the design of these assays (Table 3). The first proof of the concept was demonstrated for different antimicrobial peptides in Ref. [48]. The composition of the mixed bilayer was optimized to improve the blue-red transition in terms of intensity and response time. Lipopolysaccharide (LPS) was inserted to promote the interaction with antibacterial peptide $[50,51]$. Lipid extracts from the red alga Porphyridium cruentum strain 1380.1/PDA vesicles were tested for the colorimetric detection of melittin and of polymixin B [52]. When these lipids present a lower total number of double bonds in the acyl residues, these antibacterial peptides induce higher colorimetric response, which might be due to higher fluidity within the lipid bilayer. Increased rigidity of the lipid moieties is expected to reduce penetration of the antibacterial peptide into the lipid bilayers, then resulting in peptide binding at the lipid headgroup region within the lipid/PDA vesicles. Such surface interaction is expected to induce greater perturbation of the pendant polymer side chains within the PDA matrix.

Table 3. PDA vesicles for detection of antibacterial peptides.

\begin{tabular}{|c|c|c|c|c|c|}
\hline $\begin{array}{l}\text { Composition of the } \\
\text { Bilayer }\end{array}$ & $\begin{array}{c}\text { Encapsulated } \\
\text { Probe }\end{array}$ & $\begin{array}{c}\text { Type of } \\
\text { Transduction }\end{array}$ & Nature of Antibiotic & $\begin{array}{l}\text { Antibiotic } \\
\text { LOD }(\mu \mathrm{M})\end{array}$ & Reference \\
\hline DMPC/PCDA & No & Colorimetry & $\begin{array}{l}\text { K7L-melittin } \\
\text { Magainin II }\end{array}$ & 100 & [48] \\
\hline POPC & $\begin{array}{l}\text { Dipicolinic } \\
\text { acid } / \mathrm{Tb}^{3+}\end{array}$ & Fluorescence & alamethicin & 0.25 & [49] \\
\hline LPS/DMPC/PCDA & No & Colorimetry & $\begin{array}{c}\text { Indolicidin analog } \\
\text { (proline replaced by alanine) }\end{array}$ & 30 & [50] \\
\hline LPS/DMPC/PDA & No & Colorimetry & Polymixin B derivatives & 3 & [51] \\
\hline $\begin{array}{l}\text { Lipid extracts from the red } \\
\text { algae Porphyridium } \\
\text { cruentum strain } \\
\text { 1380.1/PCDA }\end{array}$ & No & Colorimetric & $\begin{array}{l}\text { Melittin } \\
\text { Polymixin B }\end{array}$ & $\begin{array}{l}1 \\
1\end{array}$ & [52] \\
\hline DMPC/TCDA & No & Colorimetry & $\begin{array}{c}\text { Antimicrobial } \\
\text { membrane-active metabolites } \\
\text { of soil fungi (strain 08-29-2) }\end{array}$ & & [53] \\
\hline DMPE/TRCDA & No & Colorimetry & $\begin{array}{l}\text { Nisin } \\
\text { Antibacterial peptides }\end{array}$ & & [12] \\
\hline
\end{tabular}

DMPC: 1,2-dimyristoylphosphatidylcholine; LOD: limit of detection; LPS: lipopolysaccharides; PCDA: PCDA: 10,12-pentacosadyinoic acid; POPC: palmitoyl oleoyl phosphatidylcholine; TCDA, TRCDA: 10,12-tricosadiynoic acid.

Phospholipid vesicles inserting highly fluorescent dye allowed the very sensitive detection of alamethicin, an antibiotic peptide [49]. 
The antimicrobial properties of metabolites of soil microfungi were tested through a colorimetric assay using PDA-based vesicles [53]. This assay was also applied to the high throughput screening of peptides-specifically bacteriocins—produced by lactic acid bacteria [12]. Figure 8 presents the percentage of color change of 1,2-dimysristoyl-sn-glycero-3-phosphoethanolamine (DMPE)/10,12-tricosadiynoic acid (TRCDA) vesicles treated with $50 \mu \mathrm{L}$ cell-free supernatant of 54 lactic acid bacteria strains.

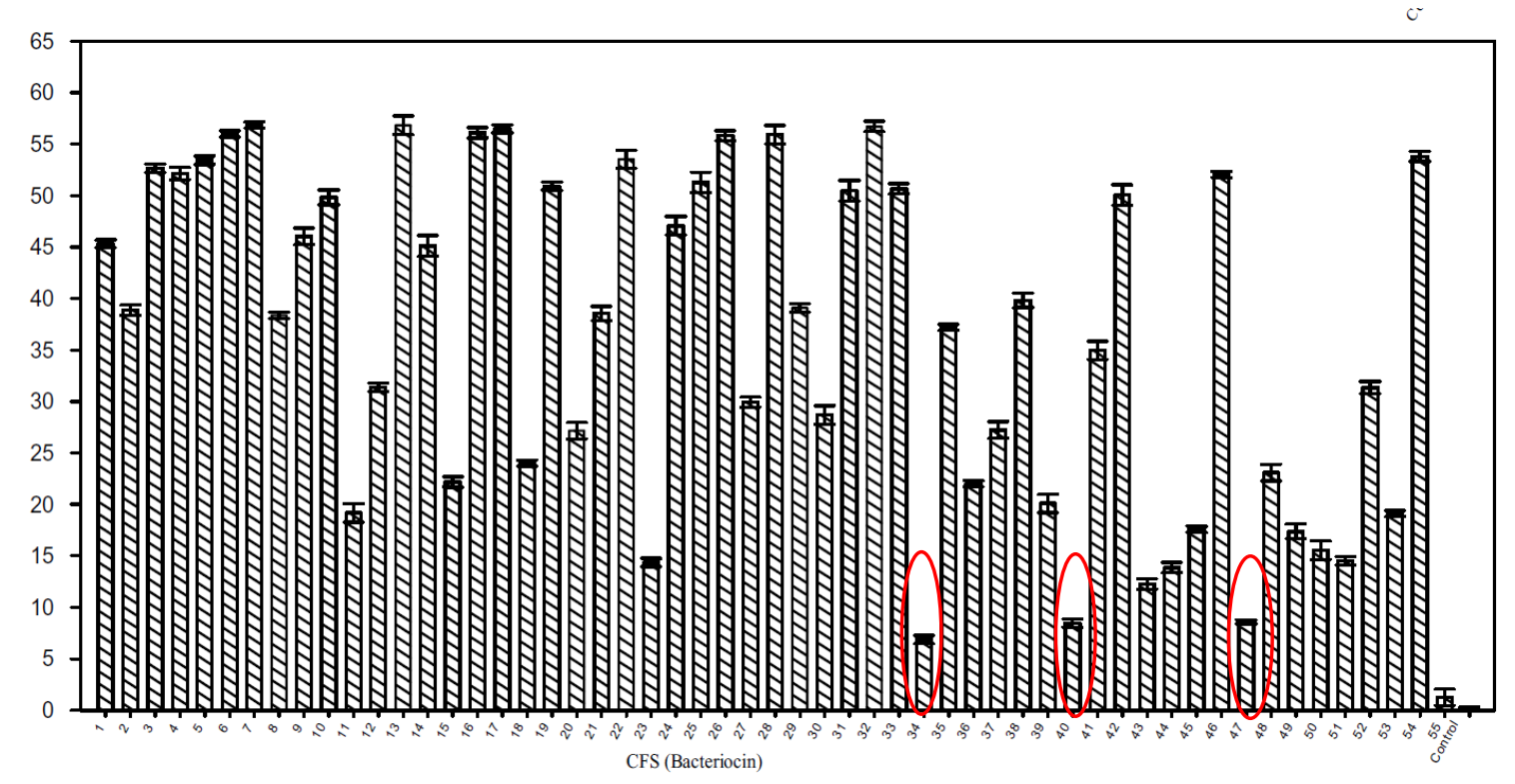

Figure 8. Color change of DMPE/TRCDA vesicles treated with $50 \mu \mathrm{L}$ cell-free supernatant of 54 lactic acid bacteria strains. Reprinted with permission from [12]. Copyright 2017 Springer Nature.

It appears that for lactic acid bacteria strains LV39 (well 34), LB52 (well 40) and LB64 (well 47) the colour change is weak, compared to that of the other strains. These strains were considered to be bacteriocin non-producers and some of the other strains with a colorimetric response higher than $50 \%$, as bacteriocin producers.

PDA based liposome arrays for antibiotic detection, with PIP2 phospholipids as neomycin receptors, were schematized [54].

\section{PDA Vesicle Based Assays for Detection of Influenza Viruses}

PDA vesicle-based assays were developed mainly for the detection of influenza viruses (cf Table 4). Influenza virus particles are enveloped by a lipid bilayer to which the hemagglutinin (HA) lectin is anchored. HA binds to terminal a-glycosides of sialic acid on cell-surface glycoproteins and glycolipids, initiating cell infection by the virus. The same type of interaction was then biomimicked on the PDA vesicle surface. The first proof of concept of the direct detection of influenza viruses through a red-blue transition of sialic acid bound to functionalized PDA vesicles was described in 1995 [55]; a detection limit of $11 \times 10^{7}$ virus particles was obtained through colorimetric measurements. The same strategy was also proposed in Ref. [56-58]: sialic acid was grafted on $\beta$-glucoside and sialic and lactose moieties were grafted on a glucoside chain for insertion in the PDA layer. Different other types of virus receptor were grafted onto PDA moieties: antibodies [59,60] and peptides [61]. 
Table 4. PDA vesicles for detection of viruses.

\begin{tabular}{|c|c|c|c|c|c|}
\hline Composition of the Bilayer & $\begin{array}{l}\text { Diameter of } \\
\text { Vesicles }\end{array}$ & $\begin{array}{c}\text { Type of } \\
\text { Transduction }\end{array}$ & Type of Virus & Virus LOD & Reference \\
\hline $\begin{array}{c}95 \% \text { PCDA } / 5 \% \text { sialic acid } \\
\text { derivatized PCDA }\end{array}$ & & colorimetry & Influenza & $\begin{array}{l}11 \times 10^{7} \text { virus } \\
\text { particles }\end{array}$ & [55] \\
\hline $\begin{array}{c}95 \% \text { PCDA } / 5 \% \text { sialic acid } \\
\text { derivatized PCDA }\end{array}$ & & colorimetry & Influenza & $\begin{array}{c}8 \times 10^{7} \text { virus } \\
\text { particles }\end{array}$ & [56] \\
\hline PCDA $/ 5 \%$ S-sialo PCDA & & colorimetry & Influenza X-31 & $0.78 \mathrm{HAU}$ & [57] \\
\hline $\begin{array}{l}\text { PDMA/DMPC/G1/G2 } \\
\text { G1: sialic acid- } \beta \text {-glucoside } \\
\text { G2: lactose- } \beta \text {-glucoside }\end{array}$ & $10-20 \mathrm{~nm}$ & colorimetry & $\begin{array}{l}\text { H5N1 Avian } \\
\text { influenza }\end{array}$ & $\begin{array}{c}10 \mathrm{ng} / \mathrm{mL} \\
\text { hemagglutinin }\end{array}$ & [58] \\
\hline $\begin{array}{c}\text { PCDA } \\
\text { Anti-H5N1 monoclonal antibody } \\
\text { grafted on vesicle surface }\end{array}$ & $117 \mathrm{~nm}$ & $\begin{array}{l}\text { colorimetry } \\
\text { fluorescence }\end{array}$ & $\begin{array}{l}\text { H5N1 Avian } \\
\text { influenza }\end{array}$ & $\begin{array}{c}30 \mathrm{ng} / \mathrm{mL} \\
\text { HAQ } \\
1 \mathrm{ng} / \mathrm{mL} \text { HAQ }\end{array}$ & [59] \\
\hline $\begin{array}{c}\text { PCDA/DMPC } \\
\text { Anti-HA monoclonal antibody } \\
\text { grafted on vesicle surface }\end{array}$ & & colorimetry & H5 influenza & 0.53 copies $/ \mu \mathrm{L}$ & [60] \\
\hline PEP-PCDA & $\sim 50 \mathrm{~nm}$ & colorimetry & $\begin{array}{c}\text { H1N1 } \\
\text { influenza }\end{array}$ & $10^{5} \mathrm{PFU}$ & {$[61]$} \\
\hline
\end{tabular}

\section{Conclusions and Future Directions}

This review presents the state-of-the-art of mixed PDA based vesicles formulated to mimic cell membranes and how they constitute actual nanosensors for the direct detection of bacteria or viruses, of bacterial toxins (bacterial virulence) and of antibacterial and antiviral peptides, through direct blue-red transition or through the passive release of encapsulated probes.

The colorimetric assays based on these PDA based vesicles are very cheap and easy to handle. They have been applied to the high throughput screening of toxins of natural origin (fungi [53] and bacteria [12]) through the design of a biosensing platform [12]. They have also been applied to rapid bacterial detection in food [32,40]. It has been observed that the vesicle encapsulation method, leading to an amplification effect, provides a lower detection limit, through the electrochemical detection of redox probes or the optical detection of fluorescent probes.

However, there are still important bottlenecks that limit the development of PDA vesicle-based bioassays. In aqueous solution, the sensitivity of PDA vesicles is usually unsatisfactory for the main applications in medical diagnostic and food safety. To increase the color change, a high concentration of analyte is required. The reversibility of PDA vesicle-based bioassays is also attractive to obtain a reusable sensor. Reversible responses can only be achieved by heating, $\mathrm{pH}$ change or UV light and no PDA sensors for biochemical analytes are actually reversible. Rigorous theoretical studies and simulations of the important transitions, leading to the color change are required to develop a clearer understanding of their origin. Improvement of stability under various conditions is a major concern, particularly rehydration efficiency to enable dry sensor forms to be developed that would be a necessary step towards the potential commercialization of point of care systems based on microarrays of PDA vesicles. Some cryoprotectants could be used for this purpose [62].

The ultimate solution to all these issues will enable the development of highly sensitive PDA vesicle-based biochips for the commercialization of convenient rapid tests, such as points-of-care for medical diagnostics, intelligent wound dressing or colorimetric tests for food safety.

Acknowledgments: Estelle Lebègue thanks the EC for financial support through a Marie Skłodowska Curie Individual Fellowship.

Conflicts of Interest: The authors declare no conflict of interest. 


\section{References}

1. Ivnitski, D.; Abdel-Hamid, I.; Atanasov, P.; Wilkins, E. Biosensors for detection of pathogenic bacteria. Biosens. Bioelectron. 1999, 14, 599-624. [CrossRef]

2. Okada, S.; Peng, S.; Spevak, W.; Charych, D. Color and Chromism of Polydiacetylene Vesicles. Acc. Chem. Res. 1998, 31, 229-239. [CrossRef]

3. Fendler, J.H. Surfactant vesicles as membrane mimetic agents: Characterization and utilization. Acc. Chem. Res. 1980, 13, 7-13. [CrossRef]

4. Bally, M.; Bailey, K.; Sugihara, K.; Grieshaber, D.; Vörös, J.; Stâdler, B. Liposome and lipid bilayer arrays towards biosensing applications. Small 2010, 22, 2481-2497. [CrossRef] [PubMed]

5. Liu, Q.; Boyd, B.J. Liposomes in biosensors. Analyst 2013, 138, 39-409. [CrossRef] [PubMed]

6. New, R.C.C. Liposomes: A Practical Approach; Oxford University Press: Oxford, UK, 1990; ISBN 13-978-0199630776.

7. Kang, D.H.; Jung, H.S.; Lee, J.; Seo, S.; Kim, J.; Kim, K.; Suh, K.Y. Design of Polydiacetylene-Phospholipid Supramolecules for Enhanced Stability and Sensitivity. Langmuir 2012, 28, 7551-7556. [CrossRef] [PubMed]

8. Thet, N.T.; Jamieson, W.D.; Laabei, M.; Mercer-Chalmers, J.D.; Jenkins, A.T.A. Photopolymerization of Polydiacetylene in Hybrid Liposomes: Effect of Polymerization on Stability and Response to Pathogenic Bacterial Toxins. J. Phys. Chem. B 2014, 118, 5418-5427. [CrossRef] [PubMed]

9. Scindia, Y.; Silbert, L.; Volinsky, R.; Kolusheva, S.; Jelinek, R. Colorimetric detection and fingerprinting of bacteria by glass-supported lipid/polydiacetylene films. Langmuir 2007, 23, 4682-4687. [CrossRef] [PubMed]

10. Kim, G.; Song, S.; Lee, J.; Kim, J.M. Size-controlled fabrication of supramolecular vesicles for the construction of conjugated polymer sensors with enhanced optical properties. Langmuir 2010, 26, 17840-17842. [CrossRef] [PubMed]

11. Lee, J.; Jeong, E.J.; Kim, J. Selective and sensitive detection of melamine by intra/inter liposomal interaction of polydiacetylene liposomes. Chem. Commun. 2011, 47, 358-360. [CrossRef] [PubMed]

12. Yadav, M.K.; Kumar, V.; Singh, B.; Tiwari, S.K. Phospholipid/Polydiacetylene Vesicle-Based Colorimetric Assay for High-Throughput Screening of Bacteriocins and Halocins. Appl. Biochem. Biotechnol. 2017, 182, 142-154. [CrossRef] [PubMed]

13. Kim, J.M.; Ji, E.K.; Woo, S.M.; Lee, H.; Anh, D.J. Immobilized polydiacetylene vesicles on solid substrates for use as chemosensors. Adv. Mater. 2003, 15, 1118-1121. [CrossRef]

14. Choi, J.M.; Yoon, B.; Choi, K.; Seol, M.L.; Kim, J.M.; Choi, Y.K. Micropatterning polydiacetylene supramolecular vesicles on glass substrates using a pre-patterned hydrophobic thin film. Macromol. Chem. Phys. 2012, 213, 610-616. [CrossRef]

15. Lee, J.; Kim, H.J.; Kim, J. Polydiacetylene liposome arrays for selective potassium detection. J. Am. Chem. Soc. 2008, 130, 5010-5011. [CrossRef] [PubMed]

16. Park, M.K.; Kim, K.W.; Ahn, D.J.; Oh, M.K. Label-free detection of bacterial RNA using polydiacetylene-based biochip. Biosens. Bioelectron. 2012, 35, 44-49. [CrossRef] [PubMed]

17. Park, C.H.; Kim, J.P.; Lee, S.W.; Jeon, N.L.; Yoo, P.J.; Sim, S.J. A direct, multiplex biosensor platform for pathogen detection based on cross-linked polydiacetylene (PDA) supramolecules. Adv. Funct. Mater. 2009, 19, 3703-3710. [CrossRef]

18. Chevalier, Y.; Pourchet, S.; Brunel, S.; Le Perchec, P.; Gallot, B. Spontaneous formation of zwitterionic vesicles: Chemical structure vesicle formation relationships. Prog. Colloid Polym. Sci. 1997, 105, 224-227. [CrossRef]

19. Ariza-Carmona, L.; Martín-Romero, M.T.; Giner-Casares, J.J.; Perez-Morales, M.; Camacho, L. Elastic nanocomposite structures formed by polyacetylene-hemicyanine mixed films at the air-water interface. J. Phys. Chem. C 2013, 117, 21838-21848. [CrossRef]

20. Obeid, S.; Ceroi, A.; Mourey, G.; Saas, P.; Elie-Caille, C.; Boireau, W. Development of a NanoBioAnalytical platform for "on-chip" qualification and quantification of platelet-derived microparticles. Biosens. Bioelectron. 2017, 93, 250-259. [CrossRef] [PubMed]

21. Jackman, J.A.; Saravanan, R.; Zhang, Y.; Tabaei, S.R.; Cha, N.J. Correlation between membrane partitioning and functional activity in a single lipid vesicle assay establishes design guidelines for antiviral peptides. Small 2015, 11, 2372-2379. [CrossRef] [PubMed]

22. Jelinek, R.; Silbert, L. Biomimetic approaches for studying membrane processes. Mol. BioSyst. 2009, 5, 811-818. [CrossRef] [PubMed] 
23. Vamvakaki, V.; Chaniotakis, N.A. Pesticide detection with a liposome-based nano-biosensor. Biosens. Bioelectron. 2007, 22, 2848-2853. [CrossRef] [PubMed]

24. Petaccia, M.; Giansanti, L.; Leonelli, F.; La Bella, A.; Gradella Villalva, D.; Mancini, G. Fluorescent lipid based sensor for the detection of thymidine phosphorylase as tumor biomarker. Sens. Actuators B Chem. 2017, 245, 213-220. [CrossRef]

25. Ma, Z.; Li, J.; Liu, M.; Cao, J.; Zou, Z.; Tu, J.; Jiang, L. Colorimetric Detection of Escherichia coli by Polydiacetylene Vesicles Functionalized with Glycolipid. J. Am. Chem. Soc. 1998, 120, 12678-12679. [CrossRef]

26. Ma, Z.; Li, J.; Jiang, L.; Cao, J.; Boullanger, P. Influence of the Spacer Length of Glycolipid Receptors in Polydiacetylene Vesicles on the Colorimetric Detection of Escherichia coli. Langmuir 2000, 16, 7801-7804. [CrossRef]

27. Kim, K.W.; Choi, H.; Lee, G.S.; Ahn, D.J.; Oh, M.K. Effect of phospholipid insertion on arrayed polydiacetylene biosensors. Colloids. Surf. B Biointerfaces 2008, 66, 213-217. [CrossRef] [PubMed]

28. Dogra, N.; Li, X.; Kohli, P. Investigating Ligand-Receptor Interactions at Bilayer Surface Using Electronic Absorption Spectroscopy and Fluorescence Resonance Energy Transfer. Langmuir 2012, 28, 12989-12998. [CrossRef] [PubMed]

29. Villalobos, P.; Chávez, M.I.; Olguín, Y.; Sánchez, E.; Valdés, E.; Galindo, R.; Young, M.E. The application of polymerized lipid vesicles as colorimetric biosensors for real-time detection of pathogens in drinking water. Electron. J. Biotechnol. 2012, 15. [CrossRef]

30. Wu, W.; Zhang, J.; Zheng, M.; Zhong, Y.; Yang, J.; Zhao, Y.; Wu, W.; Ye, W.; Wen, J.; Wang, Q.; et al. An Aptamer-Based Biosensor for Colorimetric Detection of Escherichia coli O157:H7. PLoS ONE 2012, 7, e48999. [CrossRef] [PubMed]

31. De Oliveira, T.V.; Soares, N.F.F.; Silva, D.J.; de Andrade, N.J.; Medeiros, E.A.A.; Badaró, A.T. Development of PDA/Phospholipids/Lysine vesicles to detect pathogenic bacteria. Sens. Actuators B Chem. 2013, 188, 385-392. [CrossRef]

32. De Oliveira, T.V.; Soares, N.F.F.; de Andrade, N.J.; Silva, D.J.; Medeiros, E.A.A.; Badaró, A.T. Application of $\mathrm{PCDA} / \mathrm{SPH} / \mathrm{CHO} /$ Lysine vesicles to detect pathogenic bacteria in chicken. Food Chem. 2015, 172, 428-432. [CrossRef] [PubMed]

33. Zhang, Y.; Fan, Y.; Sun, C.; Shen, D.; Li, Y.; Li, J. Functionalized polydiacetylene-glycolipid vesicles interacted with Escherichia coli under the $\mathrm{TiO}_{2}$ colloid. Colloids Surf. B Biointerfaces 2005, 40, 137-142. [CrossRef] [PubMed]

34. Kolusheva, S.; Shahal, T.; Jelinek, R. Peptide-membrane interactions studied by a new phospholipid/polydiacetylene colorimetric vesicle assay. Biochemistry 2000, 39, 15851-15859. [CrossRef] [PubMed]

35. Xu, D.; Cheng, Q. Surface-Bound Lipid Vesicles Encapsulating Redox Species for Amperometric Biosensing of Pore-Forming Bacterial Toxins. J. Am. Chem. Soc. 2002, 124, 14314-14315. [CrossRef] [PubMed]

36. Peng, T.; Cheng, Q.; Stevens, R.C. Amperometric Detection of Escherichia coli Heat-Labile Enterotoxin by Redox Diacetylenic Vesicles on a Sol-Gel Thin-Film Electrode. Anal. Chem. 2000, 72, 1611-1617. [CrossRef] [PubMed]

37. Kim, H.J.; Bennetto, H.P.; Halablab, M.A.; Choi, C.; Yoon, S. Performance of an electrochemical sensor with different types of liposomal mediators for the detection of hemolytic bacteria. Sens. Actuators B Chem. 2006, 119, 143-149. [CrossRef]

38. Thet, N.T.; Jenkins, A.T.A. An electrochemical sensor concept for the detection of bacterial virulence factors from Staphylococcus aureus and Pseudomonas aeruginosa. Electrochem. Commun. 2015, 59, 104-108. [CrossRef]

39. Ma, G.; Cheng, Q. Vesicular Polydiacetylene Sensor for Colorimetric Signaling of Bacterial Pore-Forming Toxin. Langmuir 2005, 21, 6123-6126. [CrossRef] [PubMed]

40. Silbert, L.; Ben Shlush, I.; Israel, E.; Porgador, A.; Kolusheva, S.; Jelinek, R. Rapid chromatic detection of bacteria by use of a new biomimetic polymer sensor. Appl. Environ. Microbiol. 2006, 72, 7339-7344. [CrossRef] [PubMed]

41. Nagy, J.O.; Zhang, Y.; Yi, W.; Liu, X.; Motari, E.; Song, J.C.; Lejeune, J.T.; Wang, P.G. Glycopolydiacetylene nanoparticles as a chromatic biosensor to detect Shiga-like toxin producing Escherichia coli $\mathrm{O}_{157}: \mathrm{H}_{7}$. Bioorg. Med. Chem. Lett. 2008, 18, 700-703. [CrossRef] [PubMed] 
42. Zhou, J.; Tun, T.N.; Hong, S.; Mercer-Chalmers, J.D.; Laabei, M.; Young, A.E.R.; Jenkins, A.T.A. Development of a prototype wound dressing technology which can detect and report colonization by pathogenic bacteria. Biosens. Bioelectron. 2011, 30, 67-72. [CrossRef] [PubMed]

43. Dos Santos Pires, A.C.; Soaresa, N.F.F.; da Silva, L.H.M.; da Silva, M.C.H.; De Almeida, M.V.; Le Hyaric, M.; de Andrade, N.J.; Soares, R.F.; Mageste, A.B.; Reis, S.G. A colorimetric biosensor for the detection of foodborne bacteria. Sens. Actuators B Chem. 2011, 153, 17-23. [CrossRef]

44. Laabei, M.; Jamieson, W.D.; Lewis, S.E.; Diggle, S.P.; Jenkins, A.T.A. A new assay for rhamnolipid detectionimportant virulence factors of Pseudomonas aeruginosa. Appl. Microbiol. Biotechnol. 2014, 98, 7199-7209. [CrossRef] [PubMed]

45. Haas, S.; Hain, N.; Raoufi, M.; Handschuh-Wang, S.; Wang, T.; Jiang, X.; Schönherr, H. Enzyme Degradable Polymersomes from Hyaluronic Acid-blockpoly( $\varepsilon$-caprolactone) Copolymers for the Detection of Enzymes of Pathogenic Bacteria. Biomacromolecules 2015, 16, 832-841. [CrossRef] [PubMed]

46. Park, J.; Ku, S.K.; Seo, D.; Hur, K.; Jeon, H.; Shvartsman, D.; Seok, H.K.; Mooney, D.J.; Lee, K. Label-free bacterial detection using polydiacetylene liposomes. Chem. Commun. 2016, 52, 10346-10349. [CrossRef] [PubMed]

47. Thet, N.T.; Alves, D.R.; Bean, J.E.; Booth, S.; Nzakizwanayo, J.; Young, A.E.R.; Jones, B.V.; Jenkins, A.T.A. Prototype Development of the Intelligent Hydrogel Wound Dressing and Its Efficacy in the Detection of Model Pathogenic Wound Biofilms. ACS Appl. Mater. Interfaces 2016, 8, 14909-14919. [CrossRef] [PubMed]

48. Kolusheva, S.; Boyer, L.; Jelinek, R. A colorimetric assay for rapid screening of antimicrobial peptides. Nat. Biotechnol. 2000, 18, 225-227. [CrossRef] [PubMed]

49. Rausch, J.M.; Wimley, W.C. A High-Throughput Screen for Identifying Transmembrane Pore-Forming Peptides. Anal. Biochem. 2001, 293, 258-263. [CrossRef] [PubMed]

50. Halevy, R.; Rozek, A.; Kolusheva, S.; Hancock, R.E.W.; Jelinek, R. Membrane binding and permeation by indolicidin analogs studied by a biomimetic lipid/polydiacetylene vesicle assay. Peptides 2003, 24, 1753-1761. [CrossRef] [PubMed]

51. Katz, M.; Tsubery, H.; Kolusheva, S.; Shames, A.; Fridkin, M.; Jelinek, R. Lipid binding and membrane penetration of polymyxin B derivatives studied in a biomimetic vesicle system. Biochem. J. 2003, 375, 405-413. [CrossRef] [PubMed]

52. Rozner, S.; Kolusheva, S.; Zvi, C.; Dowhan, W.; Eichler, J.; Jelinek, R. Detection and analysis of membrane ineractions by a biomimetic colorimetric lipid/polydiacetylene assay. Anal. Biochem. 2003, 319, 96-104. [CrossRef]

53. Mehravar, M.; Sardari, S. Screening of antimicrobial membrane-active metabolites of soil microfungi by using chromatic phospholipid/polydiacetylene vesicles. J. Mycol. Med. 2011, 21, 188-197. [CrossRef] [PubMed]

54. Seo, S.; Kwon, M.S.; Philipps, A.W.; Seo, D.; Kim, J. Highly sensitive turn-on biosensors by regulating fluorescent dye assembly on liposome surfaces. Chem. Commun. 2015, 51, 10229-10232. [CrossRef] [PubMed]

55. Reichert, A.; Nagy, J.O.; Spevak, W.; Charych, D. Polydiacetylene Liposomes Functionalized with Sialic Acid Bind and Colorimetrically Detect Influenza Virus. J. Am. Chem. Soc. 1995, 117, 829-830. [CrossRef]

56. Charych, D.; Cheng, Q.; Reichert, A.; Kuziemko, G.; Stroh, M.; Nagyl, J.O.; Spevak, W.; Steven, R.C. A 'litmus test' for molecular recognition using artificial membranes. Chem. Biol. 1996, 3, 113-120. [CrossRef]

57. Song, J.; Cheng, Q.; Zhu, S.; Stevens, R.C. «Smart» materials for biosensing devices: Cell-mimicking supramolecular assemblies and colorimetric detection of pathogenic agents. Biomed. Devices 2002, 4, $213-221$. [CrossRef]

58. Deng, J.; Sheng, Z.; Zhou, K.; Duan, M.; Yu, C.; Jiang, L. Construction of Effective Receptor for Recognition of Avian Influenza H5N1 Protein HA1 by Assembly of Monohead Glycolipids on Polydiacetylene Vesicle Surface. Bioconj. Chem. 2009, 20, 533-537. [CrossRef] [PubMed]

59. Dong, W.; Luo, J.; He, H.; Jiang, L. A reinforced composite structure composed of polydiacetylene assemblies deposited on polystyrene microspheres and its application to H5N1 virus detection. Int. J. Nanomed. 2013, 8, 221-232. [CrossRef]

60. Jiang, L.; Luo, J.; Dong, W.; Wang, C.; Jin, W.; Xia, Y.; Wang, H.; Ding, H.; Jiang, L.; He, H. Development and evaluation of a polydiacetylene based biosensor for the detection of H5 influenza virus. J. Virol. Methods 2015, 219, 38-45. [CrossRef] [PubMed] 
61. Song, S.; Ha, K.; Guk, K.; Hwang, S.G.; Choi, J.M.; Kang, T.; Bae, P.; Jung, J.; Lim, E.K. Colorimetric detection of influenza A (H1N1) virus by a peptide-functionalized polydiacetylene (PEPPDA) nanosensor. RSC Adv. 2016, 6, 48566-48570. [CrossRef]

62. Chen, C.; Han, D.; Cai, C.; Tang, X. An overview of liposome lyophilization and its future potential. J. Controlled Release 2010, 142, 299-311. [CrossRef] [PubMed] 